\title{
LIMITATIONS ON THE AMENDING POWER IN THE CORPORATE CONTRACT
}

In dealing with incorporation certificates setting special requirements for certain corporate actions, courts have been troubled by the persuasiveness of two conflicting approaches. The formation of a business corporation is thought of as involving a contractual arrangement by the incorporators, as set forth in the certificate of incorporation as well as in the bylaws and resolutions, all operating within the framework of the controlling body of corporation law. ${ }^{x}$ This contract regulates the management of the enterprise, the distribution of its gains and losses, and the other correlative rights and duties of its participants. Nevertheless courts have tended to assume that a legislature had not left these significant internal arrangements to the discretion of individual incorporators, at first because corporate charters were regarded as special legislative grants of privilege, and later because corporations were recognized as important to our economy. ${ }^{2}$ Norms set down by statute have been interpreted by many courts as representing public policy per se. ${ }^{3}$ Thus deviation from these norms, rather than actual or potential damage to an identifiable group, has been the criterion applied by these courts to strike down articles or bylaws. 4

From an early date in our economic history legislatures often felt the need to revise the statutes governing internal corporate arrangements, and, after some initial difficulty with regard to existing corporations, found it generally possible to do so under their reserved power to alter or amend corporate charters. ${ }^{5}$ It was also thought necessary to enable each corporation to revise and modernize its internal structure. The legislatures, by progressive stages, eventually per-

\footnotetext{
I These corporate documents are said to form a hierarchy with a provision in a superior document overriding any conflicting regulation in a document below it in rank. See Gaskill v. Gladys Belle Oil Co., I6 Del. Ch. 289, 296, I46 Atl. 337, 340 (rg29). In this aspect they resemble more a political constitution than an ordinary contract. But consistently with the underlying contractual rationale courts have applied the rules of estoppel and reformation, which tend to modify the effect of the hierarchical theory as all the documents are regarded as evidence of the underlying agreement. Cases involving estoppel: Elliott v. Lindquist, 356 Pa. 385, 52 A. 2d I80 (1947); see note I69 A.L.R. I374 (1947); 7 Univ. Chi. L. Rev. 379 (1940), noting Frank v. Wilson Co., 24 Del. Ch. 237, 9 A. 2d 82 (I939). Reformation cases include: Pratt-Low Preserving Co. v. Jordan, 217 Cal. 292, 18 P. 2d 676 (1933); Brown v. Little Brown Co., 269 Mass. 102, 168 N.E. 521 (x929); see Cristal v. Petry, 275 App. Div. 550, 90 N.Y.S. $2 d$ 620 (1949).

2 The corporation was postulated as a fictional entity, created by the state and distinct from its incorporators, which must therefore conform to the pattern in which it was created. See McNulta v. Corn Belt Bank, 164 Ill. 427, 45 N.E. 954 (1897).

3 See Benintendi v. Kenton Hotel, Inc., 294 N.Y. II2, II8, 60 N.E. 2d 829, 83 I (I945) ("[T]he Legislature, for reasons thought by it to be sufficient. ..."); Clausen v. Leary, II3 N.J. Eq. 324, 329, I66 Atl. 623, 625 (1933) ("... subversive of the statute"); Leviton v. North Jersey Holding Co., 106 N.J. Eq. 517, 520, 151 Atl. 389, 390 (1930) ("... fraud on the statute....").

4 Validity of Variations from the Norm in Corporate Structure, 28 Col. L. Rev. 366 (1928).

$s$ Power of the State to Alter Corporate Charters, 3 I Col. L. Rev. II63 (I93I).
} 
mitted a given majority of the stockholders of a corporation to alter nearly all existing arrangements. ${ }^{6}$ This amending power included the power to make fundamental and organic changes, an authority incompatible with the contractual theory of corporations. Earlier cases dealt with the amending power as qualified by the intention of the parties to the corporate contract, ${ }^{7}$ and "fundamental" amendments were disallowed. ${ }^{8}$ More recent cases speak of the incorporators as contracting in contemplation of the statutorily prescribed amending power, ${ }^{9}$ and therefore have upheld even basic changes in the rights of the corporate participants. ${ }^{\text {xo }}$ To prevent excesses in the exercise of this expanded power the courts tried to impose equitable limitations in the form of standards of reasonableness, fairness, and corporate need. ${ }^{\text {II }}$ The necessary indefiniteness of the tests, the complexity of the factual situations, and the great strategic advantages of the controlling interests all contributed to render equitable control ineffective. ${ }^{\text {Iz }}$ The wide dispersion of stock holdings and the devices tending to centralize control of corporations in a small fraction of the ownership increased this general inadequacy of public supervision for the protection of minority and nonvoting stock classes.

Hence minority or nonvoting shareholders now frequently attempt to protect their interests by securing special provisions in the corporate documents prohibiting certain actions or changes, or conditioning them on a special class or extraordinary percentage vote. ${ }^{33}$ The effectiveness of these provisions largely depends on whether they may operate to limit the majority's amending power

'Berle and Means, The Modern Corporation and Private Property 207-I9 (1932); see IIl. Rev. Stat. (I949) c. 32, \& 157.52, I Ill. Bus. Corp. Act Ann. 235-47 (I947). Compare Pa. Stat. Ann. (Purdon, I938) tit. 15, § 2852-80I with the earlier statute, I92I Pa. L. Ir59, Act of $25^{\text {th }}$ May I921, no. $426 \$ 4$. The process is continuing. Compare Cal. Corp. Code (Deering, x 948) \& 3602 with Cal. Corp. Code (Deering Supp., x949) $\$ \$ 3601,3602$.

${ }^{7}$ See Blatchford v. Ross, 54 Barb. (N.Y.) 42 (1869); cases discussed in Dodd, Dissenting Stockholders and Amendments to Corporate Charters, 75 U. of Pa. L. Rev. 585, and 723 (I927).

${ }^{8}$ Curran, Minority Stockholders and the Amendment of Corporate Charters, 32 Mich. L. Rev. 743, 747-52 (1934).

9 See Western Foundry Co. v. Wicker, 403 IIl. 260, 282, 85 N.E. 2d 722, 732 (r949); Franzblau v. Capital Securities Co., 2 N.J. Super. 517, 523, 64 A. 2d 644, 647 (I949); Fartford Accident and Indemnity Co. v. W. S. Dickey Clay Mfg. Co., 26 Del. Ch. 4II, 24 A. 2d 3I5, 322 (1942).

ro Berle and Means, op. cit. supra note 6; 4 Univ. Chi. I. Rev. I39 (I936), noting Sutton v. Globe Knitting Works, 276 Mich. 200, 267 N.W. 815 (I936).

Ix Rohrlich, Law and Practice in Corporate Control I28-68 (I933); Ballantine, Corporations (Rev. ed., I946) $\$ \S 278,278 \mathrm{a}$. But see Maddock v. Vorclone Corp., I7 Del. Ch. 39, I47 Atl. 255 (I929).

I2 See Latty, Fairness-The Focal Point in Preferred Stock Arrearage Elimination, 29 Va. I. Rev. I (I942); Dodd, Fair and Equitable Recapitalizations, 55 Harv. L. Rev. 780 (I942).

${ }^{{ }_{3}}$ Stevens, Voting Rights of Capital Stock and Shareholders, II Univ. Chi. J. Bus. 3II, 33, 3I6, 3I7 (r938); Sears, The New Place of the Stockholder 227 (I929); Rohrlich, Organizing Corporate and Other Business Enterprises $\$ 10.04$ (1949). 
as set down in the corporation statute. The consideration of this question has been complicated by a prevalent failure to distinguish between the exercise of the corporate amending power and the legislature's use of the reserved power. ${ }^{24}$

The reserved power of the legislature is axiomatically not limitable by private agreement, ${ }^{\mathrm{r} 5}$ and corporate arrangements are necessarily subject to it. Whether these arrangements are similarly subject to the corporate members' amending power depends first on the legislature's intent as expressed in the relevant statute, and then on the intent of the incorporators as expressed in their underlying agreement. Thus there is little ground for a blanket assumption that this amending power is as illimitable as the reserved power. Nevertheless this premise underlies the recent New Jersey decision in Warren v. 536 Broad Street Corp. ${ }^{16}$ In that case there was a certificate provision that the corporate assets might not be sold without the concurrence of three-fourths of the stockholders. The relevant statute allowed the insertion in the certificate of incorporation of "any provision creating, defining, limiting and regulating the powers of the corporation, its directors and stockholders or any class of stockholders," 17 but also provided that the certificate could be amended by a two-thirds vote of the stockholders. ${ }^{18} \mathrm{~A}$ majority holder controlling just two-thirds of the stock proceeded to amend the certificate to eliminate the three-fourths provision, and a minority holder sought an injunction. Both the New Jersey lower and appellate courts reasoned that since the statute is a part of every corporate charter, and therefore is included in the contract of the minority stockholders,

24 This confusion seems to have resulted from the following circumstances. The charter was originally a single document, a special legislative act, and amendments to it were secured by petitioning the legislature. See Ruggles v. Illinois, I08 U.S. 526, 534 (1883); Curry v. Scott, $54 \mathrm{~Pa} .270$ (1867); Ballantine, Corporations (Rev. ed. I946) 35-38. The term "charter" now refers to the articles of incorporation together with the general statute, and either statutory changes or corporate amendments are often loosely described as amendments to the charter. Cases cited I Prentice-Hall Corp. Serv. I ro2r (r947); 7 Fletcher, Cyclopedia of Private Corporations (I93I) $\$ \$ 37$ I2-3724 (I93r). The amending power had been extended by legislative action so that many cases turned on whether the statutes, under which challenged amendments had been made, exceeded the legislative authority to alter the charters of previously organized corporations. Dodd, op. cit. supra note 7 at 723-44; 3 Univ. Chi. L. Rev. 327, noting Keller v.Wilson \& Co., $2 x$ Del. Ch. I3, I80 Atl. 584 (I935). Some courts and text writers completed the identification by speaking of the reserved power being exercisable either by the legislature itself or by the majority of the stockholders to whom the legislature had delegated it. See Breslav v. New York \& Queens Electric Light \& Power Co., 249 App. Div. I8I, I84, 29 I N.Y. Supp. 932, 936 (1936); Peters v. United States Mortgage Co., I3 Del. Ch. II, I5, I I4 Atl. 598, 600 (I92I); Hinckley v. Schwarzschild \& Sulzberger Co., Io7 App. Div. 470, 478, 480, 95 N.Y. Supp. $357,363,365$ (1905). Fletcher, op. cit. supra, $\$ \$ 3712-3724$. It is difficult to say whether this confusion of terminology and theory has changed the outcome of any actual cases. Certainly it has obscured and obstructed consideration of the problem.

15 See Looker v. Maynard, I79 U.S. 46 (I900); Daniel v. Tyrrell \& Garth Investment Co., I27 Tex. 2r3, 93 S.W. $2 d 372$ (I936); cases cited Fletcher, op. cit. supra note I4, at $\$ 3630$.

${ }^{16} 6$ N.J. Super. r7o, $7 \circ$ A. $2 d 782$ (r950), affirming 4 N.J. Super. 584, 68 A. $2 d$ I 75 (r949).

${ }^{17}$ N.J. Rev. Stat. (I937) tit. I4, c. $2, \S 3$ (g), as amended N.J. Acts I944, c. 2 r5.

${ }^{28}$ N.J. Rev. Stat. (I937) tit. I4, c. II, $\$ \S I, 2$. 
the three-fourths provision is applicable only if not amended through the statutorily granted power. The amendment was held valid and the injunction denied, neither court making any reference to the permissive statutory language. ${ }^{19}$

The Warren case dealt with the rights of common stockholders, who have generally exercised a weaker claim on the protection of the courts than have the holders of preferred and nonvoting stock. Other factors, however, make the decision more disturbing. The corporation involved was small and closely held, and most of the original incorporators still participated. The appellate division's opinion does not refer to any economic necessity for the change, and the lower chancery court specifically rejected this as a basis for the decision. ${ }^{20}$ The limitation on the power to take the basic step of transferring the corporate assets was specific and unambiguous. Even though this protective provision required only a slightly greater majority than did the statute, the court here permitted its invalidation by the arbitrary will of the majority holder. ${ }^{2 x}$

The statutory provisions allowing contractual limitations on the power of a prescribed majority to make radical changes in the corporate structure are so clear as to be seldom litigated. The wording of the New Jersey Statute set out above is a common form of such provision..$^{22}$ It is difficult to see what meaning this wording can have if it does not apply to invalidate the amendment in the Warren case. A similar New York statute has been interpreted as authorizing a provision in the articles prohibiting the changing of the number of directors except by unanimous consent, although the statute elsewhere allowed a majority to so act.23 Another common statutory provision allows the certificate of

x9 The Chancery Court in its lengthier and more articulate opinion relies explicitly on the rigid statutory framework premise in reaching its decision: "[T]he $75 \%$ vote requirement would have to yield to the transcendent force of the statutory power granted to the stockholders. Any provision conflicting with the statutory grant or reservation would be subversive of the statute and would be deemed illegal and unenforceable." Warren v. 536 Broad Street Corp., 4 N.J. Super. 584, 594, 68 A. 2 d x75, I8o (I949). Compare King v. Ligon, I80 S.C. 224, 232, I85 S.E. 305,308 (I936).

${ }^{20} 4$ N.J. Super. 584, 592, 68 A. 2 d 175, I 79 (1949).

2x A closely related situation, and one which illustrates sharply how far the amending power has been extended, involves amendments altering voting rights and powers. Maddock v. Vorclone Corp., x7 Del. Ch. 39, I47 Atl. 255 (I929); Morris v. American Public Utilities Co., I4 Del. Ch. 136, r 22 Atl. 696 (r923). But cf. Brown v. McLanahan, r48 F. 2d 703 (C.A. 4th, r945).

22 Compare Cal. Corp. Code (Deering Supp., 1949) § 305(c); Del. Rev. Code (I935) § 2037(8); N.Y. Gen. Corp. Law (McKinney, I943) c. 2, § 13; Ohio Code Ann. (Throckmorton, 1948) $\S 8623-4(8)$.

${ }_{23}$ "It is true that this [certificate] provision is in conflict with the statutory regulation for increase of directors, but, unless it was intended by [the statute, now Gen. Corp. Law c. 2, \$13] to allow the corporators ... to prescribe regulations for the conduct of its affairs and limitations on the power of the corporation and its members different from those prescribed by the statute, the privilege... would be of little or no efficacy. Of course this privilege must be exercised in one direction. It must limit, not increase, the powers of the corporation or those of its directors or stockholders. . . . The privilege granted . . . was therefore necessarily intended to increase the rights of the minority." Ripin v. Atlantic Mercantile Co., 205 N.Y. 442, 446, 98 N.E. 855,856 (19r2); see Cristal v. Petry, 275 App. Div. 550, 90 N.Y. S. 2 d 620 (I949). 
incorporation to require for any corporate action the vote of a larger percentage of stock than the statute requires. ${ }^{24}$ Other states couch the various voting requirements in general or nonmandatory terms- "at least two-thirds" or as operating "unless otherwise provided." 25

The method by which the contractual rights of the minority were defeated in the Warren case is anticipated by the Ohio code. That code provides that if a proposed amendment would authorize any particular corporate action which the existing articles allow only by a specified vote of the shareholders, the amendment also requires the specified vote. ${ }^{26}$ Unless the statutes allowing limitations on the amending power are to be read as requiring a specific literal limitation rather than an agreement implying such limitation, such a result should be reachable without express legislative command. The transparent device of accomplishing in two steps what is forbidden in one caused no difficulty in a recent Delaware case. A charter provision requiring the consent of holders of 75 percent of the preferred stock on amendments affecting their rights and preferences had itself been amended, $5^{\circ}$ percent of the preferred concurring, so as to reduce the 75 percent requirement to 60 percent. When the corporation proceeded at its next meeting to sharply reduce the rights of the preferred holders by corporate amendment, with only 72 percent of the preferred concurring, the Chancellor held both amendments invalid since not passed by the special 75 percent preferred vote. The complaining minority in the Delaware case presented a stronger claim for equitable relief than did the complainants in the Warren case. Nevertheless, the situations are indistinguishable if the premise is granted that corporate contracts which threaten no one with unfair damage, and violate no public policy, should be enforced. ${ }^{27}$

Circumstances seem to indicate that the legislative extension of the amending power was largely prompted by the influence of those in control of corpora-

24 Cal. Corp. Code (Deering Supp., r949) $\$ \S 3632$, 390r, 4107; Del. Rev. Code (I935) $\S 2037$ (II); Ill. Rev. Stat. (r949) c. 32, \& 157.I46; N.Y. Stock Corp. Law (McKinney Supp., I949) $\& 9$ (d).

2s Ill. Rev. Stat. (I949) c. 32, \$§ I57.53c, I57.64, I57.72, I57.76; Ohio Code Ann. (Throckmorton, I948) \& 8623-15; Pa. Stat. Ann. (Purdon, I938) tit. I5, \$\$ 2852-3 II, 805, 902, I 102; Unif. Bus. Corp. Act $\$ \S 37$ (II), $38(\mathrm{II}, \mathrm{III})$, pp. 3-4 (r928); see Ehaney v. Chesebro, I92 Wis. 532, 213 N.W. 315 (1927); Wolf v. Lutheran Mutual Life Ins. Co., 236 Iowa $334, x 8$ N.W. $2 d$ 804 (r945) (semble).

${ }^{26}$ Obio Code Ann. (Throckmorton, I948) § 8623-15.

${ }^{27}$ Sellers v. Joseph Bancroft \& Sons Co., 23 Del. Ch. 13, 2 A. 2 d I08 (1938). But cf. Aldridge v. Franco Wyoming Oil Co., 24 Del. Ch. I26, 7 A. 2 d 753 (1939), aff'd 24 Del. Ch. 349, I4 A. 2d 380 (I940). In a much older and largely similar case, Blatchford v. Ross, 54 Barb. (N.Y.) 42 (I8g6), the court reached the same result by reference to cases requiring unanimity for basic changes. The Aldridge case concerned the election of directors. The courts are less likely to uphold special provisions requiring extraordinary votes for the day to day operations of the company, apparently on the theory that the latter provisions are more likely to cause corporate paralysis. Authorities cited notes 3,4 supra. 
tions, and by the desire of each state to keep corporate revenues. ${ }^{28}$ Corporations must have some capacity for readjustment to meet unexpected business circumstances. ${ }^{29}$ Perhaps also early corporations were so inflexibly organized as to disable them from competing successfully with newer corporations having more flexible internal structures. But consistent with the assumptions of the economy, it is difficult to see how the state has the kind of interest in the health and longevity of a business arrangement which would justify it in removing the matter from the discretion of those directly concerned..$^{\circ}$

Many courts insist that special provișions significantly affecting the rights of shareholders should be in the articles of incorporation rather than in the bylaws or elsewhere. In this manner these provisions may have relative permanence as well as notoriety. ${ }^{3 x} \mathrm{~A}$ common statutory requirement is that such provisions be printed in the stock certificates, in a further effort to provide for actual notice. ${ }^{32}$ It seems fair that such noncharter provisions as vary the corporation's structure from the statutory norm be valid only against those who were shareholders at the time of the provision's passage, or against those who have had reasonable opportunity to get actual notice of the provision. But as to charter provisions, if a purchaser relied on the value estimate of the market and the judgment of the incorporators when he purchased his stock, he should

${ }^{28}$ See dissenting opinion of Brandeis, J. in Liggett Co. v. Lee, 288 U.S. 517, 54I, at 577 (1933); Garrett, Where to Incorporate, $37 \mathrm{Mll}$. Bar J. 386 (x949).

29 Dodd, Amendment of Corporate Articles Under the New Ohio General Corporation Act, 4 U. of Cin. L. Rev. 129 (1930). But cf. Benintendi v. Kenton Hotel, Inc. 294 N.Y. I I 2, I20, 60 N.E. 2d 829, 832 (1945): "Every corporation is empowered to make by-laws. . . . But a corporation need not provide any machinery at all for amending its by-laws and for such an omission it could not be accused of an attempt to escape from the regulatory framework set up by law. ... [O]nce proper by-laws have been adopted, the matter of amending them is, we think, no concern of the State."

${ }^{30}$ See Morris v. Broadview, Inc., 328 Ill. App. $267,273,65$ N.E. $2 d 605,609$ (I946): "In considering whether any contract is against public policy, it should be remembered that it is to the interests of the public that persons should not be unnecessarily restricted in their freedom to make their own contracts. Agreements are not held to be void ... . unless they be clearly contrary to what the Constitution, the statutes, or the decisions of the courts have declared to be the public policy, or unless they be manifestly injurious to the public welfare. Courts must act with care in extending those rules which say that a given contract is void because against public policy, since, if there be one thing more than any other which public policy requires, it is that men of full age and competent understanding shall have the utmost liberty of contract, and that their contracts, when entered into fairly and voluntarily, shall be held sacred and shall be enforced by the courts."

The freedom to make business arrangements must include the freedom to make them binding and stable. See Sharp, Movement in Supreme Court Adjudication, 46 Harv. L. Rev. 36r, 366-72 (x933).

${ }^{32}$ Cristal v. Petry, 275 App. Div. 550, 90 N.Y.S. 2d 620 (I949); Tennant v. Epstein, 356 Iil. 26, I89 N.E. 864 (r934); Gaskill v. Gladys Belle Oil Co., r6 Del. Ch. 289, x46 Atl. 337 (I929); Nickolopoulos v. Sarantis, I02 N.J. Eq. 585, I4I Atl. 792 (1928). Compare note I supra.

${ }^{32}$ Del. Rev. Code (I935) § 2045; Ill. Rev. Stat. (I949) c. 32 , § I57.21; Pa. Stat. Ann. (Purdon, $x_{93} 8$ ) tit. $15, \S 2852-607(5)$; Unif. Bus. Corp. Act, $\S$ I5 $_{5}(\mathrm{f})$ (1928). 
not later be allowed to remake their decisions to the detriment of the contractual rights of others. ${ }^{33}$ If the real danger is harm to future purchasers of the stock without notice of the special provision, this seems one situation in which both policy and legislative declaration prescribe freedom for the incorporators at the expense of some safety for the unwary purchaser of stock.

That most stockholders are so inert as not to protect their position against majority and managerial despotism would seem to plead encouragement of those that do seek protection. Informed participants should be able to include special protective measures in their corporate arrangements. A company may contract itself into eventual paralysis, in which it is unable to pursue its normal business activities, so that dissolution or bankruptcy and resulting expensive litigation appear as the only outcome. But there is no basis for believing that a legislature may better foresee these dangers than the original incorporators, whether they be the participants in a small concern or the responsible underwriters marketing the securities of a large undertaking. No minority or even majority should be empowered to cause wastage and idleness of resources because of a contract right. In recognition of this many states have codified as "deadlock provisions" the old power of equity to decree dissolution under appropriate circumstances. 34 When an intra-corporate difficulty reaches this stage a strong public interest is involved, and no contract can be upheld which detracts from the power of the courts to remedy the difficulty.

A further danger which is emphasized as an argument for the greatly expanded amending power is that corporate paralysis and dissolution might be precipitated by an extortionate or spiteful minority. ${ }^{35} \mathrm{~A}$ solution to this problem more satisfactory than general removal of limitations on the majority power to amend lies in specific application of the control which equity has over the use of all corporate powers to the right of the minority to block a given action..$^{6}$

${ }_{33}$ ". . . [W] [Wile it is quite desirable that corporations . . . should have ample proper latitude in making readjustments to meet new and unexpected business conditions, it is even more important that the contractual rights of stockholders of all classes of stock shall be upheld by the courts under all circumstances." Concurring opinion of Judge White in General Investment Co. v. American Hide \& Leather Co., 98 N.J. Eq. 326, 332, at 338, 129 Atl. 244, 246, at 249 (1925).

34 Petition of Collins-Doan Co., 3 N.J. 382,70 A. 2 d 159 (I949) (dissolution under deadlock statute); Morse v. Metropolitan S.S. Co., 87 N.J. Eq. 2 I7, I0o Atl. 219 (Igr7), mod. 88 N.J. Eq. 325, I02 Atl. 524 (IgI7) (dissolution under inherent power of court of equity). The statutes cover many varying degrees of adequacy: Cal. Corp. Code (Deering, I949) $\$ 4650$, 465 I (d); N.J. Rev. Stat. (Supp., I939) tit. I4, c. I3, \& I.r; N.Y. Gen. Corp. Law (McKinney, I943) c. 7, $\$$ 7I(3), 9I(3) (McKinney Supp., I949) c. 7, § 103; Pa. Stat. Ann. (Purdon, I938) tit. $15, \$ 2852-1107$.

35 See King v. Ligon, I80 S.C. 224, I85 S.E. 305 (I936); Dodd, op. cit. supra note 29; The Right to Divest Accumulated Accrued Arrears on Cumulative Preferred Stock Upon Corporate Reorganization, 4 U. of Newark L. Rev. 323, 330 (I939).

${ }^{36}$ As stated by Berle and Means nearly two decades ago, "[A]ll powers granted to a corporation or to the management of a corporation, or to any group within a corporation, whether derived from statute or charter or both, are necessarily and at all times exercisable only for the 
When an amendment, which would otherwise be valid under the statute, is blocked by a minority acting under a special charter provision limiting the amending power, equity should grant relief if the majority can prove mala fides on the part of the dissenters. This test would be difficult to meet, but, since its burden would fall on the litigant having superior resources and strategic position, it should prove more workable than the often clumsy attempts to control unlimited majority powers.

\section{POLICING CONTRACTS UNDER THE PROPOSED COMMERCIAL CODE}

If the court finds the contract or any clause of the contract to be unconscionable it may refuse to enforce the contract or strike any unconscionable clauses and enforce the contract as if the stricken clause had never existed. ${ }^{x}$

This provision is presently being considered for inclusion in the new Uniform Commercial Code by the Commissioners on Uniform State Laws. The provision and the commissioners' comments on it invite analysis of the possible effects of interfering with contractual obligations because they are "unconscionable." The latest comment indicates one area in which increased judicial control may be expected. Prior comments and the language of the provision provide incentive for further speculation.

At present the commissioners appear primarily concerned with the difficulties resulting from an application of existing rules of assent to form contracts. The law generally insists that acceptance of a document, particularly when signed, indicates agreement to all its terms. ${ }^{2}$ However, the average individual becoming a party to a form contract actually agrees to a type of transaction in which only such matters as price, quantity, and quality are of interest. ${ }^{3}$ The

ratable benefit of all the shareholders as their interest appears." The Modern Corporation and Private Property 248 ( 1932 ). This principle should apply to any power given a minority or special class to block a given action.

I Uniform Commercial Code $\S 2-302$ (tent. draft, May, I950). The draft considered by the commissioners before the latest revision in May read, "If the court finds the contract or any clause of the contract to be unconscionable it may refuse to enforce the contract or strike any unconscionable clause and enforce the rest of the contract or substitute for the stricken clause such provision as would be implied under this article if the stricken clauses had never existed" (tent. draft, Spring, I950) (emphasis added). Professor Grant Gilmore, Yale University, informed the writer of the latest revision which was unpublished at the time this article went to press. The commissioners' comment on the provision is to be rewritten to reflect the deletion in the latest revision. Actually the section omitted appears superfluous to the meaning of the clause. For example, should a clause concerning place of delivery be stricken as unconscionable, the law will still imply, without this provision, that delivery is to be at the seller's place of business. Uniform Commercial Code $\$ 2-308$ (tent. draft, Spring, I950).

2 I Williston, Contracts $\S 9 \circ A$ (1936); Rest., Contracts $\$ 70$ (1932).

3 Llewellyn, Review of Prausnitz, The Standardization of Commercial Contracts in Engglish and Continental Law, 52 Harv. L. Rev. 700 (1939). There are a number of excellent discussions concerning form contracts. For an analysis of their treatment by the courts consult 